\title{
Theories and Contemporary Development of Organizational Perspectives in Social Sciences. The founding writers of Western sociology. Part 1
}

\author{
Medani P. Bhandari, Ph.D. ${ }^{1}$ \\ ${ }^{1}$ Akamai University \\ Hawaii, USA
}

\begin{abstract}
This paper is purely theoretical in which I have illustrated the contributions of the founding theorist of Western sociology, by focusing on how they addressed (or didn't address) organizations. Then, I have discussed (in brief) the development of organizational theory and how organizational theorists are responding to the emergence of challenges to the traditional rational approaches to understanding organizations. These analyses are situated on the historical contexts include major contributions of each theorist. This research is solely based on the secondary information. Paper contents four Sections: first the work of the three founding theorists of Western Sociology, Karl Marx; Émile Durkheim and Max Weber, secondly, I have exemplified the development of organizational theory and the emergence of challenges to the traditional rational approaches to understand the organization; where $I$ have analyzed the work of Classical theorists- Max Weber, Henri Fayol, Frederick Taylor, Luther Halsey Gulick, Herbert A. Simon, Berton H. Kaplan, modern theorist- Michel Foucault, Jurgen Habermas, Jacques Derrida, Jurgen Habermas etc. Third Section covers the contemporary theories and perspectives. In this section I have exemplified how Philip Selznick, Peter Blau, James David Thompson and Charles Perrow incorporated the Weber notion of bureaucracy followed by DiMaggio, Paul, J. and Walter W. Powell etc. and in forth section, covers the feminist approach in theory building with focus of organizational analysis (with the focus of Arlene Daniels, Dorothy Smith, Marjorie DeVault, Gisela Bock and Susan James, Martha Calas, Linda Smircich etc. work). This paper has detailed footnotes quoted from the original sources and contents useful reference of the sociological theory and practices for concerned social scientist to build their knowledge base and research direction.
\end{abstract}

Index Terms - International Organizations, International Relation, Organizational Sociology, Organizational Theory, Classical Sociology, Contemporary Theories.

ASEJ - Scientific Journal of Bielsko-Biala School of Finance and Law

Volume 24, No 1 (2020), 6 pages

DOI: $10.5604 / 01.3001 .0014 .1342$

Received: 06 April 2020; Accepted: 10 April 2020

\section{INTRODUCTION}

Sociology examines the social actors' activities in the society, and social problems. Western Scholars have developed many social theories, which address the underlying causes such as social conflicts and inequalities, and the many formal and informal social organizations texts are involved in those issues. The study of social organizations is a relatively new phenomenon in sociology. Broadly its historical root can be traced from Greek civilization (Plato, Aristotle), and it mostly flourished since the Enlightenment era. However, the empirical studies show that the scientific study of organizations begins only from 19th and 20th century. Among the scholars of these centuries the contributions of Karl Marx, Ferdinand Tönnies, Émile Durkheim, Ludwig Gumplovicz, Vilfredo Pareto, and Max Weber and Talcott Parsons are considered as pillars of sociology. To answer the first question, (founding writers of Western sociology) I will only focus main three classical sociologists Max Weber (1864-1920), who introduced the concept of bureaucracy, and Karl Marx (1818-1883) and Emile Durkheim (1858-1917) who developed the concept of division of labor as founding concept of formal ground for organization sociology respectively.

Likewise to answer the second question 'development of organizational theory and how organizational theorists are responding to the emergence of challenges to the traditional rational approaches to understanding organizations' firstly, I will briefly revisit the contribution of major classical organizational theorists such as Max Weber, Henri Fayol, and Frederic Yaylor followed by the Luther Halsey Gulick and Herbert A. Simon. Several authors (Moore 2003, O'Connor 1993, Wallerstein 1974, 1998, 2000) illustrate that Weber was rational theorist. Wallerstein (1998) in his article "The Ecology and the Economy: what is rational" (online publication) states

Regular research paper: Published 30 April 2020

Corresponding author's e-mail: medani.bhandari@gmail.com

Copyright $(\mathbb{C} 2018$ This is an open access article distributed under the Creative Commons Attribution CC-BY-NC 4.0 License. 
that "Rationality is; more than we admit, in the eye of the beholder. It has something to do with the optimal means to achieve a goal, any goal, what Weber called "formal rationality." And it has something to do with the relative wisdom of the goal that is given priority, what Weber called "substantive rationality" (Rationalität materiell" (Wallerstein1998). Secondly, I will illustrate the contribution of Berton H. Kaplan, who followed the rational approach of organizational analysis in the context of social dynamism and social development. Kaplan is rarely illustrated by the mainstream organizational sociologists. Thirdly, I will briefly describe about the contemporary theoretical perspectives developed on the ground of the traditional rational approaches. This section will demonstrate the contribution of Philip Selznick, Peter Blau who are considered as the founder of organizational sociology, followed by the Charles Perrow, Paul DiMaggio and Walter Powell. In the final section (of second section), I will briefly examine the feminist approaches of organizational study, who follow the both rational and natural system perspectives of organizational analysis but challenge to the traditional Weberian notion of bureaucracy. They follow Foucault's postmodern perspectives to analyze the formal organizations. In this (final) section, I will illustrate the contributions of Arlene Daniel, Martha Calas, Linda Smircich and Jana Brewis whom I consider as a challenger of traditional perspectives of organizational study.

In the following paragraphs I will first discuss the major contributions of Marx followed by Durkheim and Weber.

\section{THE FOUNDING WRITERS OF WESTERN SOCIOLOGY}

\section{Karl Marx}

Karl Marx is one of the popular and evergreen philosophers of the 19th century. His philosophical contributions have been very important to the modern world since the beginning of the 20th century to formulate a new vision especially, in global politics, as well as in the anthropogenic socio-economic environments. Marx developed several epistemologies and also examined notions of established theories. His major focus was to examine how political and economic histories were grounded and to what extent they reveal the social reality. On the basis of historical studies, he developed his new theories on the dialectical materialistic ground. He wrote several books solely and several together with Fredric Angels. There are hundreds of books and journal articles for and against about his materialist theory of history, means, mode and forces of production, laws of historical development and particularly on his theory of ideology. His earlier writings were mainly on political economy. The Capital was the extended version of his economy writings, where he extensively discussed capital, commodity, exchange, exchange and social relation, labor (useful and abstract), values, forms of values, relationship between economy and society, theory of surplus (labor and wage) and capitalism (primitive accumulation, division of labor). He sharply criticized religion ("the opium of the people"). In addition to economy and religion he extensively engaged in political writings (actually most of his writings can be consider as political and economic writings). In his political writings Marx examines political history on the dialectical paradigm and provides new ground in politics (communist manifesto, contribution to the critique of political economy, historical origin of modern state, a critique of Hegel's philosophy of rights, etc.).

His new epistemology of reasoning (on the dialectic ground) has been always crucial and problematic to the western feudalistic society. He was mostly influenced by Hegel in his early life. However, there are clear differences between Hegel's epistemology of dialectic and Marx's dialectic materialism. Hegel focused upon how ideas and concepts can be dialectic and how logical ground can be identical. Hegel states that all things are in a continuous state of motion and change, and that general laws of motion are intrinsic to the development of the individual and history. Hegel examined world as interconnected process. This doctrine was viewed as dialectic as the principle of contradiction is identifiable in three phases i.e. affirmation or thesis, negation or antithesis and 'negation of the negation' or synthesis.

In contract to Hegel, Marx developed a different doctrine named materialistic dialectic to indicate the shift from the dominance of ideas to dominance of economic conditions (Morrison 1995 p. 312). Marx states "My dialectic method, is not only different from the Hegelian, but is its direct opposite. To Hegel, the life-process of the human brain, i.e. the process of thinking, which, under the name of 'the Idea,' he even transforms into an independent subject, is the demiurges of the real world, and the real world is only the external, phenomenal form of 'the Idea.' With me, on the contrary, the ideal is nothing else than the material world reflected by the human minds and translated into forms of thought" (Capital Afterward 1887). This narrative provides the basis of how Marx developed the epistemology of dialectic materialism. Hegel, through his dialectic approach, visualized world development as an interconnected process. Hegel did not separate person and things, and things around person.

In the other hand Marx examined how the principle of contradiction manifested itself in the form of coercive class structure, where socioeconomic history was the process of class struggle, "For Marx stages of development were related to economic production and the system of social classes" (Morrison 1995 p. 312). Marx analyzed the historical development of socio-economy in four stages i.e. "primitive community": where class relations were not developed and private ownership was not established; ancient society: system of ownership developed, where relations were based on dominance of one class over the others; feudal society: class relations were embedded in property relations, when the class of producers emerged, and the final stage was "the Capitalism" classes which are in direct opposition, leading to class struggle between capitalists and those who produce the capital (the working class). Marx did not write directly under the heading of sociology nor considered himself as a sociologist. However, Marx examined society in a dialectical way, which resulted in 
fellow theorists placing him as one of the pillars of sociological thought. His social, political and economic equations have been applied in both hard sciences and social sciences. In the Capital, Karl Marx examines how capital dominates and influences production and produces a surplus value in monetary form. He states, "Although we come across the first beginnings of capitalist production as early as the 14 th or 15 th century, sporadically, in certain towns of the Mediterranean, the capitalistic era dates from the 16th century" (Capital p. 715). Marx argues that market expansion is not a simple process but could be a forceful and difficult one. According to Marx, primitive accumulation is the historical process of separating labor from product and production. He argues that a simple production is also reproduction of the capital-labor social relationship; however, it does not act in a reciprocal way on the capitalist social system.

When Marx wrote The Capital, social structure was very different, and he might not have imagined the future of the world as it is now. When he wrote The Capital the slavery system existed and there was competition among European nations for colonization and extreme European influence on the Marx known deprived world. As a social progressive thinker and activist what he visualized was very true and very relevant to that time. His philosophy was applied and is still in use in many parts of the world as a model. Many developing world poor people still think Marxism is the best model which can free them from bourgeois feudalism.

It is hard to summarize what major theoretical contributions Marx made in sociological theory building. He pointed out that whatever he is doing is in the society and for the society "Even when I carry out scientific work. I perform a social, because human act. It is only the material of my activity like the language itself which the thinker uses which is given to me as a social product. My own existence is a social product" (Tucker 1969 , p. 89). His presence can be found in most of the subject matter of sociological epistemology. His notion of dialecticism provides new ways to examine society. Marx first examines the sociological reality through critical perspectives and proposes the optimal solution to resolve the underlying social problems. His critical reasoning on social development gave others the ground to oppose the positivist basis of social inquiry. In terms of his contribution to the sub-fields of sociology, such as in political sociology, historical sociology, organizational sociology and feminist sociology etc. he gave the insights to examine society on logical grounds. "Marx's work has been the inspiration and constant touchstone for radical critiques of management under conditions of capitalist industrial development as exemplified in debates concerning the nature of the labor process under capitalism (Braverman 1974 as cited by Starkey 1992:1). His writings on class struggle and conflict provide the basis to explore how important is power dynamism, the relationships between social elite and working class and how capital formation occurs in feudalistic and capitalist society. In general terms Marxist notions can be applied to examine critically how organizations are formed, for whom and with what purpose. Further his notions allow us to explore organizational conflict and how capital is formatted to run the organization. Marx introduced the concept of greed in possession or consumption of goods and services.

Marxist epistemology was seldom taken into consideration in the North American political, economic and sociological inquiry. I am not arguing that Marxist thought was totally ignored in the Western world; however, there were only few American sociologists who considered Marx as a sociologist prior to the Second World War. American Sociologists mostly criticized Marx as an ideologist and rejection of Marx in sociology reflected ideological differences of American sociologists (Ritzer 2000). Organizational sociology as a discipline began in America in the 1950s among those who did not consider Marx's notion of division of labor, people alienation to power and class and power struggle, which could suggest a way of analyzing the organization. Instead they gave more emphasis to other western theorists who leaned towards the capitalist mode of economy. However, this trend changed after the 2nd world war in American academia. Various scholars began to use Marx's epistemological position to examine social movements (civil rights movements, feminist movements etc.). Most importantly feminist scholars have been incorporating a Marxist approach of critical reasoning from the first wave to date. Within sociology, scholars (e.g. Simone de Beauvoir, Kate Millett, Shulamith Firestone, Gayatri Spivak, Ann Oakley, Juliet Mitchell and Sheila Rowbotham, Dorothy Smith etc.) began to see society deeply through Marxist perspectives. In organizational sociology new perspectives have been developed (rational, natural and open system (primarily) and environmental, demographic and ecological etc. more recently). The women scholars began to inquire with the application of critical perspectives where women stand in the organization in every sector of social life, including formal and informal social organizations, and scholars began to see the women's role in organizational structure. There are several feminist authors who have contributed to organizational theory development. Likewise, organizational sociologists also began to examine formal organizations through the application of critical and dialectical approaches. In the final section of this essay I will summarize how the Marxist approach has been incorporated in evaluating the organization, especially by feminist scholars Dorothy Smith, Chandra Talpade Mohanty, Joanna Brewis, Marta B. Calás; Linda Smircich, Judith Stacey; Barrie Thorne and Marjorie DeVault.

\section{Emile Durkheim}

Emile Durkheim is another founding writer of Western sociology. His major writings were Division of Labor in Society (1893), Rules of Sociological Method (1894), Suicide (1897) and Elementary Forms of Religious Life (1912). From 1896 he began a journal 'Annee Sociologique'; through this journal he published many articles. Durkheim's stand was opposite to Marx. He followed and developed the functionalist approach embedded in positivism. The functionalist approach was constructed under an epistemology that allows us to evaluate society as organisms. In another words the complexity of social systems is similar to the way different organisms act 
in the human body or in the lives of any living creatures. This notion of society as function which Hegel described 'as a continuous state of motion and change, and those general laws of motion are intrinsic to the development' fits with Durkheim's grounds for sociological theory building. While Hegel provided an idealistic view that society runs as an interconnected process, Durkheim followed the same track and examined the social problems with the application of Comtenian positivist philosophy. Durkheim accepted the positivistic thesis with the assumption that society can be examined as facts and facts can be observed only through scientific method. Furthermore, he also accepted Comte's idea of sociology, that "sociology as science of society could be validly constituted only when it was stripped of its metaphysical abstraction and philosophical speculation" (Morrison 1995, p. 123). Durkheim's use of scientific method to study society was unchallenged until the Second World War.

Durkheim tried to examine social functions from individual to group level. He believed that social realities exist in the form of social rules, customs and beliefs; therefore, these phenomena can be studied by focusing on social facts rather than on individuals. He thought that focusing on the individual is to ignore the larger system of social rules which forms the basis of society (Morrison 1995). Durkheim's contribution to sociology was very important, because he was the first author who considered himself as a sociologist and developed sociology as a different discipline. Durkheim defined sociology as a moral science. His theses are (1) society comes prior to the individual; (2) society as ideal; (3) production of collective conscience: individual and collective conscience will differ; (4) society is greater than the sum of its parts - this is unique to social organization, and (5) sociology is to study moral rules as part of the social organization Morrison 1995, Ritzer 2000). Durkheim saw society as social fact (society as function), introduced scientific approaches to study social phenomena and examined how social order exists in various types of society. He studied social organizations in the context of division of labor and compared traditional and modern society. He states "the bulk of the population is no longer divided according to relations of consan $\neg$ guinity, real or fictive, but according to the division of territory. All peoples who have passed beyond the clan stage are organized in territorial districts (coun $\neg$ ties, communes, etc.) which connected themselves with other districts of a similar nature which, in their turn, are often enveloped by others still more extensive (shire, province, department) whose union formed the society" (Durkheim 1893:185-6). He reexamined the earlier predecessors such as Herbert Spencer or Otto von Gierke, who had argued that societies evolved like living organisms (based on Darwinism concept). Earlier sociologist such as Goldenweiser (1917), Barnes (1920), Bellah (1959), Lammers (1978) have extensively advocated the usefulness of Durkheim in social sciences theory building. In this context Barnes examination of "Durkheim's contribution to the reconstruction of political theory" provides a good outline of to what extent Durkheim was successful in examining social and political organizations. However, Durkheim saw organization just as a functionary of social system, which was much criticized by his successors. In this regard, Charles Tilly (1981) wrote a book on "Useless Durkheim", however I think Durkheim is not useless. As Emirbayer (1996) points out, his moral sociology has something to contribute to contractual organizational relationships.

Durkheim examined religion in a deeper way. He states "A religion is a unified system of beliefs and practices relative to sacred things, that is to say, things set apart and forbidden-beliefs and practices which unite in one single moral community called a Church, all those who adhere to them" (Durkheim 1912). In the context of organization management Durkheim sees similarities with religion in the relevance of discipline (forcing or administering discipline), cohesion (bringing people together), a strong bond (vitalizing, making more lively or vigorous, to boost spirit) and euphora (a good feeling, happiness, confidence, well-being) (Durkheim 1912).

To some extent these notions were very important in maintaining social order when society was mostly influenced and guided by religious norms. In differentiating between the collective and individual consciousness, Durkheim introduced a key notion of individualism which Foucault has discussed a lot (but has not acknowledged to Durkheim). These ideas also show the similarities between Durkheim and Weber in relation to free society. Legal and administrative authorities were based on the biblical myth or the spiritual aspect of the society or backed by the religious body. Marx carefully internalized this notion of the social system, pointing out that the major cause of social classification was due to religious institutions, and developed his thesis against the existing social system. Marx indicted religion as an evil phenomenon of society and social organizations. In the following paragraphs I will write on Max Weber who is commonly considered as the founder of organizational sociology.

\section{Max Weber}

Max Weber is one of the most important sociological theorists who followed the rational ground of social reality, with influence of Kantian and Hegelian thoughts. Like Marx and Durkheim, Max Weber had various interests such as politics, history, language, religion, law and administration. There are several similarities and differences between Weber and Marx. In some cases, Weber superseded Marx in explanation of religion, ideas, values and meaning of social action: "Weber spent his life having a posthumous dialogue with the ghost of Karl Marx" (Cuff 1979). Weber's analysis refers first to economic determinism and the extent to which developments are rooted in the material base and second, the extent to which economic factors alone can be considered to be the root of social structure. Weber's thought has similarities to that of Marx because he came from almost same economic, social and intellectual environment as Marx; Weber analyzes history, politics and economics on a structural basis. They both consider space and time in changing sequence, which is very important and applicable all the time. The acceptance of timing sequence and space specification shows their long-lasting 
influence on the discipline. One way or another Marx's thought deals with one side of the coin while Weber covers another part of it. One talks collectivism and the other talks individualism. Marx sees everything under the collective scenario and from the economic viewpoint while Weber, on the other hand, looks through the individual perspective. Both offer valid insights for me, one way or another.

For Max Weber, the economic order was paramount in determining the precise position of various communities; however, other structures such as religion, ideas, status and bureaucracy are not less determining factors. He showed that the importance of people's action does not always exert influence only through economic interests. Weber argued that national bureaucracy is significant to the society and to the individual rather than the class struggle. According to Weber basic characteristics of bureaucracy are:

1) office holders personally free and subject to authority only within the scope of their impersonal official obligations;

2) hierarchy of offices;

3) spheres of competence;

4) free selection into office, filled by free contractual relationships; always free to resign;

5) candidates appointed, not elected, on basis of technical qualifications;

6) remuneration is by fixed salaries of ;

7) office is sole or primary occupation of incumbent;

8) constitutes a career; system of promotion,

9) official can't own means or appropriate position,

10) official subject to strict and systematic discipline and control in conduct of office (Scott 2003).

There can be several disagreements in terms of the current world situation however; these are still significant characteristics of sound bureaucracy. Weber emphasized the historical evidence, which he examined carefully to frame the bureaucratic order.

Max Weber addresses Capitalism as historically embedded in the religious movement of Protestantism with a focus on Calvinism (The Protestant Ethic and the Spirit of Capitalism), where religious followers are internally guided by religious thought and where individuals do not accept blame for right or wrong conduct themselves, rather they blame their God and convince themselves that it was their God's wish. He elaborates on the idea that rationalism is based on calculations of return. Weber capitalism supposes the free markets for production and labor. A similar argument is found in Durkheim's elaboration of moral religious life, and opposite arguments in Marx writings.

\section{CONCLUSION}

Marx, Durkheim and Weber had very strong influence on Hegelian philosophy. They all deal with common social problems. "The theoretical origins of the conflict, functionalist and organizational paradigms in sociology are usually seen as distinct. Common elements in the social theories of Marx, Durkheim and Weber are usually seen as common responses to the development of industrial, capitalist, democratic, bureaucratic structures" (Knapp 1986:586). Marx and Weber analyzed social problems on the common rational ground and Durkheim examined society as a function of the living organism. Their focuses were how history was developed and in what criteria and what can be learned from history to manage contemporary society. Marx directly used the dialectic paradigm of Hegel with contradiction; Durkheim did not mention Hegel, but applied positivism as Hegel noted society runs as process. All three founding authors pointed to labor as a main force for socio-economic development. Marx and Durkheim went in opposite directions, but Weber followed the middle path in analysing organization. Knapp (1986) summarizes each of these three authors' similarities and differences and also gives an account of the extent to which they were influenced by Hegel, ,Organizational sociological literature is mostly silent on the root philosophy of organization. Among these three major writers of sociology, organization sociology is based most notably on Weber's rational notion of bureaucracy. In the following section I will briefly describe other influential writers and note how organizational sociology has been developed.

\section{ACKNOWLEDGEMENT}

I acknowledge the input of Mrs. Prajita Bhandari, for creating a peaceful environment to complete this paper and insightful comments and language editing. I would also like to thank to Prameya, Kelsey, Manaslu, Abhimanyu for their insightful comments. I would also thank to Neena (our granddaughter who brought the joy in the family so, I was able to concentrate on my job). Especial thanks go to Professors Steven R. Brechin, Peter Ibarra, Marjory for their mentorship to me, without their efforts I would not be able to stand as social theorist. I would also like to thank to the Editor in Chief Prof. Jacek Piotr Binda and Associate Editor Aleksander Sapiński for their encouragements to complete this very theoretical paper. I would also like to thank to the reviewer panel for their input and comments.

\section{REFERENCES}

Braverman, H. (1974), Labor and Monopoly Capital: The Degradation of Work in the Twentieth Century. New York: Monthly Review Press.

Cuff, E.C. (1979), Perspectives in Sociology, Taylor \& Francis Group.

Durkheim, E.. (1915), The Elementary Forms of the Religious Life: A Study in Religious Sociology, Translated by Joseph Ward Swain, New York: Macmillan.

Knapp, P. (1986), Hegel's Universal in Marx, Durkheim and Weber: The Role of Hegelian Ideas in the Origin of Sociology, Sociological Forum, Vol. 1, No. 4. (Autumn, 1986), pp. 586-609.

Morrison, K. (1995), Marx, Durkheim, Weber: Formations of Modern Social Thought, London: Sage.

Ritzer G. (2000), Classical Sociological Theory, 3rd edition. New York: McGraw-Hill

Ritzer G. (2000), Modern Sociological Theory, McGraw-Hill Humanities/Social Sciences/Languages, 5th edition 
Ritzer G. (2000), The McDonaldization Thesis: Extensions and Explorations, London: SAGE

Starkey P. (1992), The early development of numerical reasoning, Congnition,43(2):93-126.

Tucker, F. (1969), White-Nonwhite Age Differences and the Accurate Assessment of the "Cost of Being Negro" Social Forces, Vol. 47, No. 3 .343345 